\title{
Molecular cloning and expression of a novel catechol 2,3-dioxygenase gene from the benzoate meta-cleavage pathway in Azotobacter vinelandii
}

\author{
HENRY KeIL \\ Department of Biology and Biochemistry, Brunel University, Uxbridge, Middlesex UB8 $3 P H, U K$
}

(Received 14 June 1989; revised 17 November 1989; accepted 2 January 1990)

\begin{abstract}
Azotobacter vinelandii strain 206 degrades benzoate via the meta-cleavage pathway. In a genomic library derived from this organism a clone was obtained which carried and expressed the gene for the third enzyme in this pathway, catechol 2,3-dioxygenase (EC 1.13.11.2), on a $5.9 \mathrm{~kb}$ SalI restriction fragment. The structural gene was more precisely mapped on an internal $1.6 \mathrm{~kb}$ EcoRI fragment which, after insertion into expression vectors, directed the synthesis of a $33 \mathrm{kDa}$ polypeptide. The gene showed very little or no homology with isofunctional genes derived from Pseudomonas. Comprehensive substrate specificity analysis showed significant differences between the specific activities obtained from the cloned gene product and extracts derived from Azotobacter itself.
\end{abstract}

\section{Introduction}

Azotobacter is well-known for its efficient nitrogen fixation under obligatory aerobic conditions and has therefore been the target of extensive studies on its nitrogen fixation (nif) genes (Bishop et al., 1986; Jacobsen et al., 1986; Robson, 1986). Independent investigations into the architecture of the Azotobacter genome have revealed the presence of multiple genome copies for both Azotobacter vinelandii (Sadoff et al., 1979) and Azotobacter chroococcum (Robson et al., 1984), with a copy number between 20 and 40 per cell. This high degree of polyploidy is paralleled by the approximately 10-fold greater volume of the vegetative cells of Azotobacter when compared with those of $E$. coli. The chemistry and enzymology of aromatic catabolism have mainly been investigated in soil micro-organisms of the genus Pseudomonas (Dagley, 1986); these studies have been complemented by investigations into the molecular genetics of these catabolic traits, particularly where the genes were found to be plasmid-borne (Harayama \& Don, 1985). Little information, however, is available about the catabolic activities of Azotobacter; the presence of a meta-cleavage pathway for the degradation of benzoate has been described in $A$. vinelandii strain 206 (Sala-Trepat \& Evans, 1971) but there have been no

Abbreviations: C23DO, catechol 2,3-dioxygenase; DCCD, dihydroxycyclohexadiene carboxylate dehydrogenase; HMSD, 2-hydroxymuconic semialdehyde dehydrogenase; IPTG, isopropyl $\beta$-Dthiogalactoside. studies on the genetics of this phenotype. In this report the cloning and molecular analysis of the catechol 2,3dioxygenase (C23DO) gene of the meta-cleavage pathway from this strain is described and results are presented demonstrating a low degree of homology with isofunctional genes and gene products derived from Pseudomonas.

\section{Methods}

Bacterial strains and plasmids. A list of strains used or constructed in this study is presented in Table 1.

Media and culture conditions. A. vinelandii strain 206 was grown on solid and liquid nitrogen-free minimal medium (Hardisson et al., 1969) with sodium benzoate $(15 \mathrm{mM})$ or sodium acetate $(10 \mathrm{mM})$ as carbon sources. E. coli strains were cultivated in Luria broth supplemented with the appropriate antibiotic at the following concentrations $(\mu \mathrm{g}$ $\mathrm{ml}^{-1}$ ): ampicillin, 25; tetracycline, 8; chloramphenicol, 30; kanamycin, 25.

Recombinant strains carrying expression vectors were grown at the appropriate temperature to an $\mathrm{OD}_{600}$ of 0.55 . Induction was brought about by the addition of IPTG (isopropyl $\beta$-D-thiogalactoside) ( $2 \mathrm{mM}$ final concentration with pMMB22) or by a shift in temperature to $42^{\circ} \mathrm{C}$ for $2 \mathrm{~h}$ with pPLGN1.

DNA extraction and purification. DNA was isolated from Azotobacter in a scaled-down modification of the procedure described by Sadoff $e t$ al. (1979). A $200 \mathrm{ml}$ culture was grown up to an $\mathrm{OD}_{578}$ of $1 \cdot 0$. Cells were spun down and resuspended in $1.6 \mathrm{ml} 10 \mathrm{~mm}$-Tris $/ \mathrm{HCl}, 100 \mathrm{~mm}-\mathrm{NaCl}$, pH 8.1; $0.4 \mathrm{ml} 120 \mathrm{~mm}$-Tris/ $\mathrm{HCl}, 50 \mathrm{~mm}$-EDTA, $0.4 \mathrm{mg}$ lysozyme $\mathrm{ml}^{-1}, \mathrm{pH} 8 \cdot 1$, was added followed by $2.05 \mathrm{ml} 1 \%(\mathrm{v} / \mathrm{v})$ Triton X-100, $2 \mathrm{M}-\mathrm{NaCl}, 10 \mathrm{mM}-\mathrm{EDTA}, \mathrm{pH} 8 \cdot 1$. The suspension was incubated for $10 \mathrm{~min}$ at $37^{\circ} \mathrm{C}$ during which time cell lysis occurred. Proteins were removed by addition of $0.4 \mathrm{ml} 5 \mathrm{M}$-sodium perchlorate and $4.5 \mathrm{ml}$ 
Table 1. Bacterial strains and plasmids

\begin{tabular}{|c|c|c|}
\hline Strain & Plasmid & Notes and reference \\
\hline $\begin{array}{l}\text { Azotobacter vinelandii } \\
\text { strain } 206\end{array}$ & & Sala-Trepat \& Evans (1971) \\
\hline $\begin{array}{l}\text { Alcaligenes eutrophus } \\
\text { mutant B9 }\end{array}$ & & Reiner \& Hegeman (1971) \\
\hline E. coli $\mathrm{ED} 8654$ & & metB SupE SupF hsdR hsdM (Borck et al., 1976) \\
\hline E. coli JM103 & & $\Delta\left(\right.$ lac-pro) thi strA supE endA $s b c B$ hsdR $\mathrm{F}^{\prime}$ traD36 proAB lacla z M15 (Messing et al., 1981) \\
\hline \multirow[t]{14}{*}{ E. coli $\mathrm{C} 600$} & pBR322 & Bolivar et al. (1977) \\
\hline & pBR325 & Bolivar (1978) \\
\hline & pKT230 & Bagdasarian et al. (1981) \\
\hline & pMMB22 & Bagdasarian et al. (1983) \\
\hline & pPLGN1 & Leeman et al. (1987) \\
\hline & pEKA3 & $5.9 \mathrm{~kb}$ SalI fragment from $A$. vinelandii cloned in pBR 322 \\
\hline & pEKA33 & Reverse orientation of pEKA3 in pBR322 \\
\hline & pEKA41 & $1.6 \mathrm{~kb}$ internal $E c o$ RI subfragment of pEKA3 inserted in pBR325 \\
\hline & pEKA43 & $1.5 \mathrm{~kb}$ internal EcoRI subfragment of pEKA3 inserted in pBR325 \\
\hline & pEKA45 & $2.1 \mathrm{~kb}$ internal $E c o$ RI subfragment of pEKA3 inserted in pBR325 \\
\hline & pEKA3ptac & $1.6 \mathrm{~kb}$ EcoRI subfragment of pEKA3 inserted into pMMB22 \\
\hline & pEKA3pL & Same fragment inserted into pPLGN1 \\
\hline & pEKP171ptac & $\begin{array}{l}2.1 \mathrm{~kb} \text { EcoRI subfragment of pWW15-3171 carrying the C23DOII gene of } P \text {. putida MT15 } \\
\text { (Keil } \text { et al. }(1985 a) \text { inserted into pMMB } 22\end{array}$ \\
\hline & pEKP171pL & Same fragment inserted into pPLGN1 \\
\hline
\end{tabular}

chloroform/isoamyl alcohol $(97: 3, \mathrm{v} / \mathrm{v})$ and subsequent incubation at $25^{\circ} \mathrm{C}$ for $15 \mathrm{~min}$. The aqueous phase was separated by centrifugation and extracted twice more under the same conditions. DNA was precipitated at $-20{ }^{\circ} \mathrm{C}$ by addition of 2 vols $95 \%$ (v/v) ethanol. The DNA pellet was redissolved in $2 \mathrm{ml}$ TE-buffer $(10 \mathrm{mM}-\mathrm{Tris} / \mathrm{HCl}, 1 \mathrm{mM}-$ EDTA pH 8.0) and treated with RNAase $\left(50 \mu \mathrm{g} \mathrm{ml}^{-1}\right.$ final concentration) for $1 \mathrm{~h}$ at $37^{\circ} \mathrm{C}$ and Pronase $\left(100 \mu \mathrm{g} \mathrm{ml}^{-1}\right.$ final concentration) for $2 \mathrm{~h}$ at $37^{\circ} \mathrm{C}$. The DNA was extracted twice with phenol and the aqueous phase precipitated with 2 vols ethanol: the DNA pellet was finally dissolved in $200 \mu \mathrm{l} \mathrm{TE}$ and stored at $4{ }^{\circ} \mathrm{C} ; 10 \mu \mathrm{g}$ of the DNA was used for subsequent cloning experiments. Vector and cloned DNA were purified by $\mathrm{CsCl} /$ ethidium bromide equilibrium centrifugation whereas for small scale preparations of recombinant DNA the method of Holmes \& Quigley was used (1981).

DNA cloning and manipulation. Restriction endonuclease cleavage and DNA ligations were done according to the instructions provided by the manufacturer; E. coli strains ED8654 and JM103 were transformed by standard procedures (Cohen et al., 1972). Colonies carrying recombinant plasmids expressing $\mathrm{C} 23 \mathrm{DO}$ activity were identified by the catechol spray test (Worsey et al., 1978).

DNA-DNA hybridization. DNA restriction fragments were separated by agarose gel electrophoresis and transferred to Gene Screen Plus $^{\text {TM }}$ (Du Pont) by the Southern blotting technique. The inserted fragment was separated from the vector by agarose gel electrophoresis and purified by electroelution (Maniatis et al., 1982). DNA was radiolabelled by nick-translation using $\left[\alpha^{-32} \mathrm{P}\right] \mathrm{dGTP}$ and hybridized as described previously (Keil \& Williams, 1985) in $50 \%(\mathrm{v} / \mathrm{v})$ formamide at $42^{\circ} \mathrm{C}$.

Enzyme analysis. Crude extracts of $A$. vinelandii and $E$. coli were prepared as described previously (Worsey \& Williams, 1975). The enzyme assay procedures for C23DO and HMSD (hydroxymuconic semialdehyde dehydrogenase) were taken from Sala-Trepat \& Evans (1971). DCCD (dihydroxycyclohexadiene carboxylate dehydrogenase) was assayed according to Reiner (1972). The substrate was prepared via biotransformation of benzoate using Alcaligenes eutrophus mutant B9 (Reiner \& Hegeman, 1971).
$P A G E$. Denaturing $12 \%(\mathrm{w} / \mathrm{v})$ acrylamide/bisacrylamide $(30: 0 \cdot 5)$ gels were used to resolve total cell protein as described by Laemmli (1970).

\section{Results}

\section{Cloning and physical mapping of C23DO genes from Azotobacter}

Cleavage of $A$. vinelandii genomic DNA with $B a m \mathrm{HI}$ and HindIII was found to be limited, leaving most of the DNA unrestricted in the high-molecular-mass size range. Restriction with EcoRI, SalI and $X h o I$, however, gave rise to a wide size range of fragments; hence the latter two enzymes were chosen for the construction of a genomic library from $A$. vinelandii in the two vectors pBR322 (Bolivar et al., 1977) and pKT230 (Bagdasarian et al., 1981). In a typical cloning experiment about $10^{4}$ transformants were obtained and subjected to the catechol spray test which allowed rapid identification of recombinant $E$. coli clones expressing the C23DO gene. From the SalI cloning experiment one clone was obtained carrying the C23DO gene; none was detected in the $X h o I$ cloning procedure. Analysis of the recombinant plasmid DNA in the C23DO-expressing clone revealed the presence of a $5.9 \mathrm{~kb}$ SalI insert in plasmid pEKA3. In order to physically locate the structural gene more precisely on the cloned fragment subcloning experiments were done. Plasmid pEKA3 was restricted with EcoRI and the three internal fragments were inserted into 


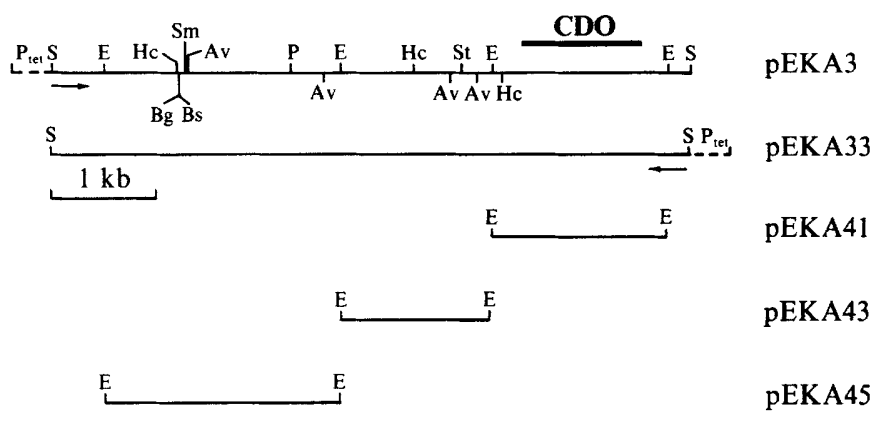

Fig. 1. Restriction map of the SalI fragment cloned from A. vinelandii. The black bar represents the location of the C23DO gene. The arrows indicate the direction of transcription from the promoter of the tetracycline-resistance gene on pBR322 ( $\left.\mathrm{P}_{\mathrm{tet}}\right)$. The various subclones generated are shown below the map. The abbreviations for restriction enzyme sites are as follows: Av, AvaI; Bg, BglII; Bs, Bst EII; E, EcoRI; Hc, HincII; P, Pst I; S, SalI ; Sm, SmaI; St, StuI. There are no sites for AsnI, BamHI, HindIII, HpaI, KpnI, SacI, SphI, XbaI and XhoI.

vector $\mathrm{pBR} 325$ generating the recombinant plasmids pEKA41, 43 and 45 (Fig. 1); the SalI insert was also reoriented in respect of the vector promoter to give pEKA33. The $1.6 \mathrm{~kb}$ EcoRI fragment was inserted into the expression vectors pMMB22 and pPLGN1 to generate $\mathrm{pEKA} 3 \mathrm{ptac}$ and $\mathrm{pEKA} 3 \mathrm{pL}$ respectively.

\section{Enzyme activities of C23DO gene products}

All enzyme studies on cloned genes were done in E. coli. The specific activity in strains carrying pEKA3 was comparatively low (Table 2) although the gene was inserted such that transcription could be initiated from the constitutive tetracycline promoter of pBR322. No C23DO activity could be detected in strains containing pEKA33, with the $5.9 \mathrm{~kb}$ SalI insert in the opposite orientation, suggesting that transcription runs from leftto-right as shown in Fig. 1 and that there are no promoter sequences functional in $E$. coli upstream of the C23DO gene on pEKA3. By enzyme analysis of additional subclones of pEKA3 such as pEKA41 and pEKA3ptac the gene was mapped to the right-hand end of the cloned SalI fragment (Table 2 and Fig. 1). In A. vinelandii strain 206, C23DO is one of a set of enzymes the expression of which is induced in the presence of the growth substrate benzoate (Table 2; Sala-Trepat \& Evans, 1971). Therefore cells containing pEKA3 were analysed for the activities of the enzymes which are adjacent in the catabolic pathway. Neither benzoate dioxygenase and DCCD, the first two enzymes of the pathway, nor HMSD, the enzyme acting on the product of C23DO activity, were detected; neither was there any significant increase in C23DO expression measured in E. coli upon addition of benzoate to the growth medium. By comparison, in $A$. vinelandii strain 206 all three enzyme activities were well-expressed and induced about 500fold in the presence of benzoate (Table 2).

\section{Analysis of substrate specificity}

The specific activities of the C23DO encoded on pEKA3 and its derivatives towards catechol and the two

Table 2. Specific activities of catabolic enzymes involved in the degradation of benzoate

A. vinelandii strain 206 was cultivated either on sodium acetate or sodium benzoate. E. coli ED8654 carrying various recombinant plasmids was grown on Luria Broth. Enzyme activities are expressed as milliunits of activity (mg protein $)^{-1}$. Values in parentheses are the ratios of activity towards 3-methyl-and 4-methylcatechol with respect to the activity towards catechol. ND, Not determined.

\begin{tabular}{|c|c|c|c|c|c|}
\hline \multirow[b]{2}{*}{ Strain/plasmid } & \multicolumn{3}{|c|}{$\mathrm{C} 23 \mathrm{DO}$} & \multirow[b]{2}{*}{ DCCD } & \multirow[b]{2}{*}{ HMSD } \\
\hline & Catechol & $\begin{array}{l}\text { 3-Methyl- } \\
\text { catechol }\end{array}$ & $\begin{array}{l}\text { 4-Methyl- } \\
\text { catechol }\end{array}$ & & \\
\hline $\begin{array}{l}\text { A. vinelandii } 206 \\
\text { (acetate-grown) }\end{array}$ & 2 & $<1$ & $<1$ & $<1$ & 1 \\
\hline $\begin{array}{l}\text { A. vinelandii } 206 \\
\text { (benzoate grown) }\end{array}$ & 980 & $44(0.04)$ & $80 \quad(0.08)$ & 350 & 790 \\
\hline E. coli/pEKA3 & 7 & $1(0 \cdot 14)$ & $0.4(0.06)$ & $<1$ & $<1$ \\
\hline E. coli/pEKA33 & $<1$ & $<1$ & $<1$ & ND & ND \\
\hline E. coli/pEKA4l & 168 & $27(0 \cdot 16)$ & $9.5(0.06)$ & ND & ND \\
\hline E. coli/pEKA3ptac & 450 & $45(0 \cdot 10)$ & $16(0.04)$ & ND & ND \\
\hline $\begin{array}{l}\text { E. coli/pEKA3ptac } \\
\text { (+ IPTG) }\end{array}$ & 4000 & $480(0 \cdot 12)$ & $250 \quad(0.06)$ & ND & ND \\
\hline E. coli/pEKP171ptac & 180 & $300(1.66)$ & $\begin{array}{ll}50 & (0.27)\end{array}$ & ND & ND \\
\hline $\begin{array}{l}\text { E. coli/pEKP171 ptac } \\
\text { (+ IPTG) }\end{array}$ & 5500 & $9800(1.77)$ & $2600 \quad(0 \cdot 46)$ & ND & ND \\
\hline
\end{tabular}


(c)

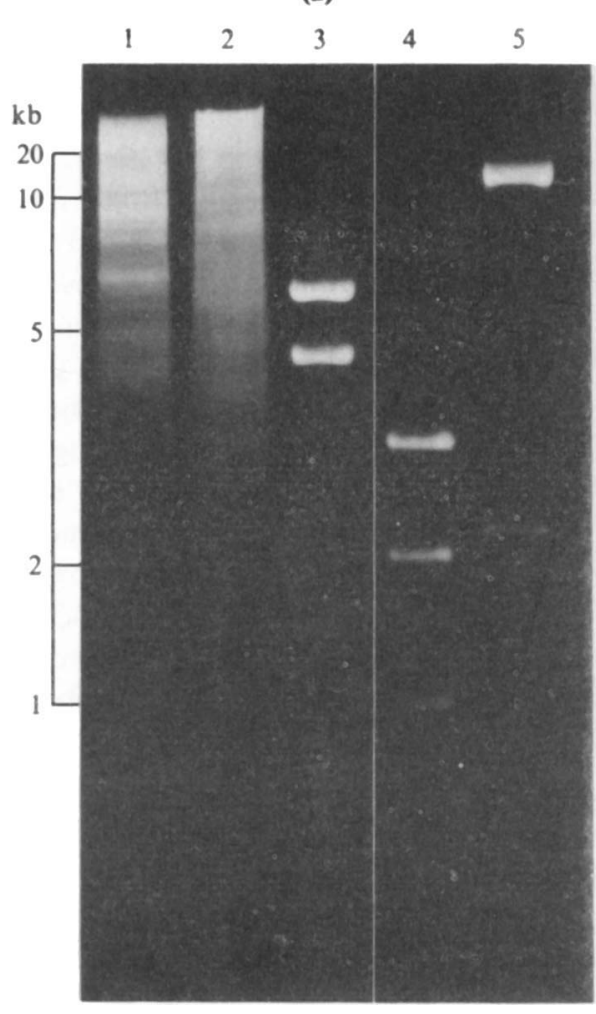

(b)

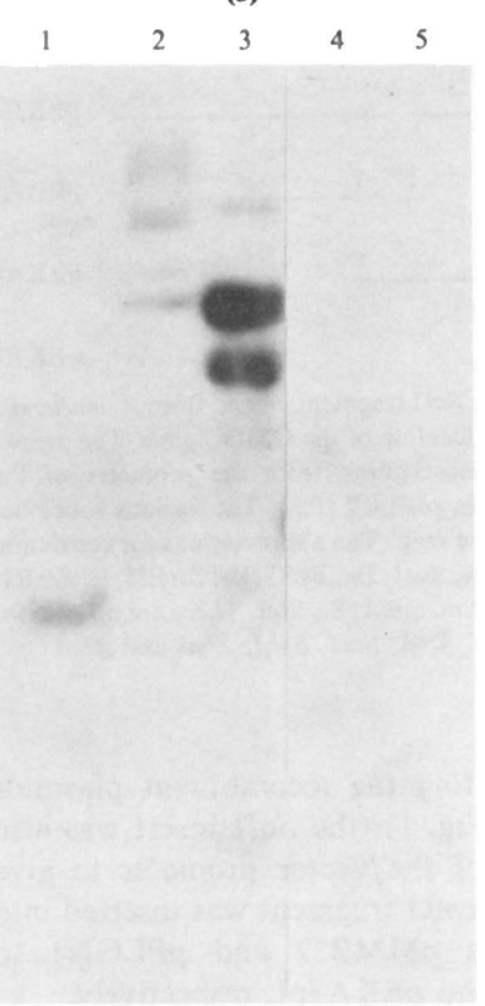

Fig. 2. Hybridization pattern of genomic DNA from $A$. vinelandii and various recombinant plasmids carrying catechol-2,3-dioxygenase genes. (a) Ethidium-bromide-stained agarose gel; (b) autoradiogram of the same gel after hybridization to radiolabelled pEKA3 DNA. Lane 1, A. vinelandii genomic DNA restricted with EcoRI; lane 2, A. vinelandii DNA restricted with $S a l \mathrm{I}$; lane 3, pEKA3 restricted with $S a l I$; lane 4, pWW 15-3171 restricted with EcoRI; lane 5, XhoI fragment XI from pWW0 inserted in pKT230, restricted with XhoI. The absence of any hybridization signal in lane 4 and 5 suggests little or no similarity of the C23DO gene from Azotobacter with isofunctional catabolic genes from Pseudomonas.

methyiated derivatives 3-methyl- and 4-methylcatechol were determined and compared with the specific activities measured in crude extracts prepared from $A$. vinelandii (Table 2). Cell extracts derived from pEKA3 all displayed similar specificity towards catechol, but showed very low activity towards 3-methylcatechol (ratio $0 \cdot 12-0 \cdot 16)$ and an even lower activity towards 4methylcatechol (ratio 0.06). Crude extracts obtained from $A$. vinelandii showed a significantly different substrate specificity pattern in respect of 3-methylcatechol: the ratio of specific activities (3-methylcatechol with respect to catechol) was much lower $(0.04)$ when compared with the equivalent ratios obtained for the cloned $\mathrm{C} 23 \mathrm{DO}$ gene products on pEKA3. On the other hand, 4-methylcatechol was only a slightly better substrate with Azotobacter crude extracts (ratio 0.08) than with the pEKA3-derived extracts (Table 2). The relative substrate specificity ratios of the C23DOII gene derived from $P$. putida MT15 and inserted in pMMB22 were significantly higher when compared with the Azotobacter data (Table 2) and in agreement with previous results obtained using different host-vector systems (Keil et al., 1985a), suggesting a less-restricted substrate specificity for this enzyme.

\section{DNA-DNA hybridization of the Azotobacter C23DO gene with Pseudomonas C23DO genes}

In order to assess the degree of homology between the C23DO gene cloned from Azotobacter and genes coding for isofunctional enzymes previously cloned from Pseudomonas TOL plasmids (Inouye et al., 1981; Keil et al., $1985 \mathrm{a}$ ) the $5.9 \mathrm{~kb} \mathrm{SalI}$ insert of pEKA3 was radiolabelled and used as a probe in DNA-DNA hybridization experiments (Fig. 2). In the SalI-restricted genomic DNA from $A$. vinelandii a $5.9 \mathrm{~kb}$ Sall restriction fragment did hybridize together with a few bands of $>9 \mathrm{~kb}$ (lane 2). A $1.6 \mathrm{~kb} \mathrm{EcoRI} \mathrm{band} \mathrm{hybridized} \mathrm{in}$ EcoRI-digested Azotobacter DNA corresponding to the internal EcoRI fragment of pEKA3. The larger bands hybridizing in the $S a l l$ restricted genomic DNA (lane 2) may suggest the presence of additional copies of the 


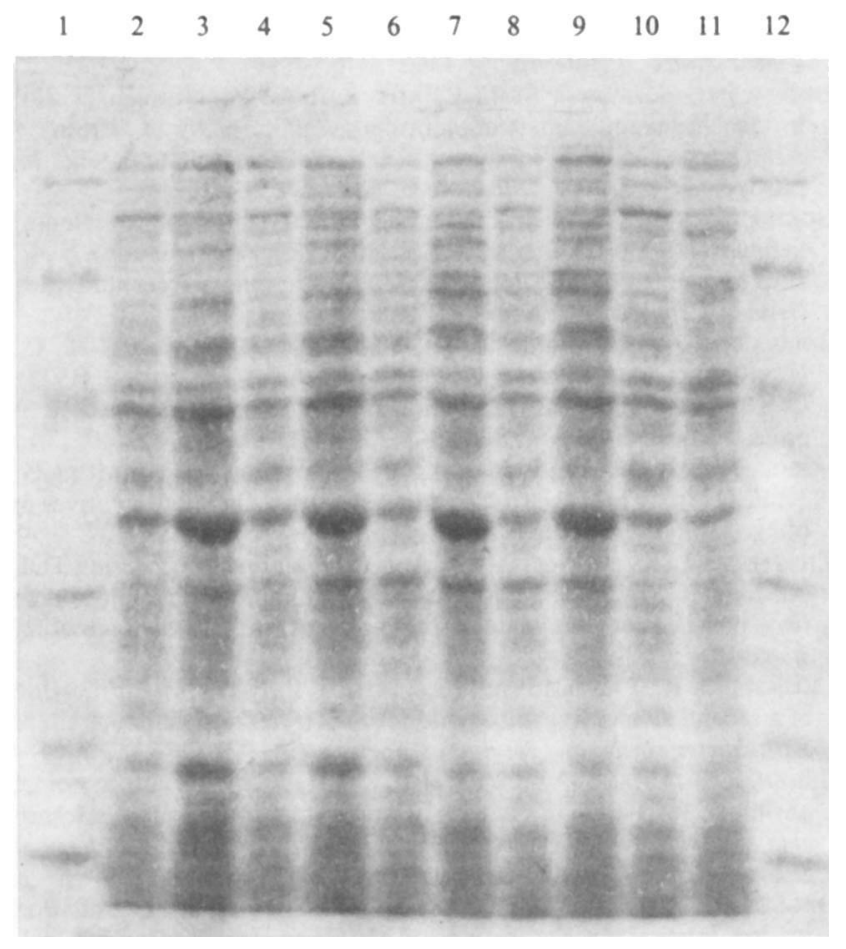

Fig. 3. SDS-PAGE of total proteins of recombinant $E$. coli strains carrying cloned C23DO genes that had (lanes 3, 5, 7, 9 and 11) or had not (lanes 2, 4, 6, 8 and 10) been induced. The samples were: pEKA3ptac (lanes 2 and 3); pEKP171 ptac (lanes 4 and 5); pEKA3pL (lanes 6 and 7); pEKP171pL (lanes 8 and 9); E. coli ED8654 (lanes 10 and 11). Lanes 1 and 12 contained standard molecular mass markers (from top to bottom: $97.4 \mathrm{kDa}, 66.2 \mathrm{kDa}, 42.7 \mathrm{kDa}, 31 \mathrm{kDa}, 21.5 \mathrm{kDa}$ and $14.4 \mathrm{kDa}$ ).

CDO gene located on conserved $1.6 \mathrm{~kb}$ internal EcoRI fragments; this is supported by the relatively strong hybridization signal shown by this restriction fragment in lane 1 . No clear positive signal was detected in the two lanes with the recombinant plasmids carrying C23DO genes derived from the Pseudomonas TOL plasmids pWW0 ( $x y l E$ gene) or pWW15 (C23DOII gene), respectively.

\section{Expression of C23DO genes cloned from Pseudomonas and Azotobacter}

The $2 \cdot 1 \mathrm{~kb} E c o \mathrm{RI}$ fragment from the recombinant plasmid pWW15-3171, known to carry the structural gene of the C23DO originally cloned from $P$. putida MT15 (Keil et al., 1985a), was inserted into the expression vectors $\mathrm{pMMB} 22$ and $\mathrm{pPLGN} 1$ to give rise to pEKP171ptac and pEKP171pL, respectively. Together with the corresponding clones pEKA3ptac and pEKA3pL carrying the C23DO gene from $A$. vinelandii, the four recombinant plasmids were transformed in $E$. coli ED8654; the protein profiles of cells that had or had not been induced were subsequently analysed by SDSPAGE. A protein of approximate molecular mass $33 \mathrm{kDa}$ was detected in extracts of all induced cells (Fig. 3). The two proteins hence appeared to be slightly smaller than the C23DO purified from $P$. putida $\mathrm{mt}-2$ with an $M_{\mathrm{r}}$ of 35000 (Nakai et al., 1983).

\section{Discussion}

This paper describes a new type of C23DO gene present in Azotobacter and unrelated to isofunctional genes isolated mainly from Pseudomonas. Previous investigations on C23DO genes from the latter genus have shown that one type appears to be widespread among different natural isolates of $P$ seudomonas. This gene was originally cloned from TOL plasmid pWW0 and called $x y l E$ (Inouye et al., 1981) and was subsequently found in similar form in other non-related TOL plasmids (Keil $e t$ $a l ., 1985 a, b$; Chatfield \& Williams, 1986; Shaw \& Williams, 1988) or in plasmids coding for the catabolism of naphthalene (Lehrbach et al., 1983; Assinder \& Williams, 1988). Most of these comparative studies have been done by DNA-DNA hybridization but comparative nucleotide sequence analysis showed a $96 \%$ similarity between $x y l E$ of pWW0 and the C23DOI gene of pWW15 (H. Keil \& P. A. Williams, unpublished results) and $80 \%$ similarity between $x y l E$ and $n a h H$, a gene coding for an isofunctional enzyme in the naphthalene catabolic pathway on plasmid NAH7 (Ghosal et al., 1987; Harayama et al., 1987). A completely different C23DO gene has been identified on the non-transmissible TOL plasmid pWW15 sharing very little or no identity with the archetypal xylE gene (Keil et al., 1985a). A third and different type of C23DO gene has now been cloned from Azotobacter. These findings could imply that the structural gene for C23DO has evolved independently several times with the $x y l E$ type being the most ubiquitous version because of its location on selftransmissible broad-host-range plasmids such as $\mathrm{pWW} 0$ or NAH7 (Benson \& Shapiro, 1978; Dunn \& Gunsalus, 1973) and/or its presence on the catabolic transposon Tn4561 (Tsuda \& lino, 1987). However, a common ancestor for these non-homologous genes in the distant past cannot be ruled out until information about their nucleotide sequence is available.

The absence of any activity of other enzymes from the catabolic pathway, in particular within the $4 \mathrm{~kb}$ region upstream of the C23DO gene in pEKA3, can be explained in two ways. Either the structural genes of the pathway are widely dispersed on the Azotobacter genome or, alternatively, the genes are located in two distinct clusters analogous to the situation in Acinetobacter where the first three genes ben $A, B, C$ coding for the enzymes converting benzoate to catechol are physically separated 
on the genome from the genes coding for the orthocleavage pathway cat $A, B, C, D \ldots$ converting catechol to 3-oxoadipate (Shanley et al., 1986; Neidle et al., 1987). In any case the absence of a tightly spaced catabolic gene cluster, characteristic of plasmid-encoded functions, suggests a chromosomal location for the catabolic genes in Azotobacter, confirmed by the absence of any plasmid DNA in strain 206 (unpublished data).

The stringent specificity of the cloned C23DO gene product for unsubstituted catechol only is not surprising since $A$. vinelandii shows poor growth on substituted benzoates such as $m$-toluate. By contrast, $P$. putida grows readily on $m$-toluate and its isofunctional enzymes display a nearly equivalent or even higher affinity towards 3-methylcatechol than towards catechol (Keil et al., 1985a; Table 2). The fact that crude extracts obtained from $A$. vinelandii show a significantly different substrate specificity compared with the cloned gene product raises the possibility of the presence of additional, as yet unidentified, C23DO genes in this organism. Three homologous copies of the nif $H$ gene coding for dinitrogen reductase have been identified by DNA-DNA hybridization on the genome of Azotobacter vinelandii (Jacobsen et al., 1986) and from the same organism three dinitrogenases with different cofactor requirements (molybdenum, vanadium and iron) and expressed under different growth conditions have been isolated (Bishop et al., 1980; Chishell et al., 1988). The question as to the presence of multiple copies of catabolic genes in Azobacter is currently being addressed by constructing and screening a random genomic library in cosmid vectors.

I would like to thank E. Remaut for the gift of plasmid pPLGN1, A. Al-Maghrabi for aid in protein gel electrophoresis and S. Keil for skilled technical assistance.

This investigation was supported by an award from the Nuffield Foundation.

\section{References}

Assinder, S. J. \& Williams, P. A. (1988). Comparisons of the meta pathway operons on NAH plasmid $\mathrm{pWW} 60-22$ and TOL plasmid pWW53-4 and its evolutionary significance. Journal of General Microbiology 134, 2769-2778.

Bagdasarian, M., Franklin, F. C. H., LuRz, R., RugCkert, B., Bagdasarian, M. M. \& Timmis, K. N. (19810. Specific purpose cloning vectors. II. Broad host range high copy numbers RSF1010derived vectors and a host vector system for gene cloning. Gene 16, 237-247.

Bagdasarian, M. M., Amann, E., Lurz, R., Rueckert, B. \& BagDasarian, M. (1983). Activity of the hybrid trp-lac (tac) promoter of Escherichia coli in Pseudomonas putida. Construction of broad-host-range, controlled expression vectors. Gene 26, 273-282.

Benson, S. \& ShapIRo, J. (1978). TOL is a broad-host-range plasmid. Journal of Bacteriology 135, 278-280.

Bishop, P. E., JARLENSKi, D. M. L. \& Hetherington, D. R. (1980). Evidence for an alternative nitrogen fixation system in Azotobacter vinelandii. Proceedings of the National Academy of Sciences of the United States of America 77, 7342-7346.

Bishop, P. E., HAwKINS, M. E. \& EADY, R. R. (1986). Nitrogen fixation in molybdenum deficient continuous culture by a strain of Azotobacter vinelandii carrying a deletion of the structural genes for nitrogenase (nifHDK). Biochemical Journal 238, 437-442.

BoLIVAR, F. (1978). Construction and characterization of new cloning vehicles. III. Derivatives of plasmid pBR322 carrying unique EcoRI sites for selection of $E c o$ RI generated recombinant DNA molecules. Gene 4, 121-136.

Bolivar, F., Rodriguez, R. L., Green, P. J., Betlach, H. C., HeYNeCKer, H. C., Boyer, H. W., Crosa, J. J. \& FalKow, S. (1977). Construction and characterization of new cloning vehicles. II. A multi-purpose cloning system. Gene 2, 95-113.

Borck, J., BegGs, J. D., Brammar, W. J., Hopkins, A. S. \& Murray, N. E. (1976). The construction in vitro of transducing derivatives of phage lambda. Molecular and General Genetics 146, 199-207.

Chatfield, L. K. \& Williams, P. A. (1986). Naturally occurring TOL plasmids in Pseudomonas strains carrying either two homologous or two non-homologous catechol 2,3-oxygenase genes. Journal of Bacteriology 168, 878-885.

Chisnell, J. R., Premakumar, R. \& Bishop, P. E. (1988). Purification of a second alternative nitrogenase from a nifHDK deletion strain of Azotobacter vinelandii. Journal of Bacteriology 170, 27-33.

Cohen, S. N., Chang, A. C. Y. \& Hsu, C. L. (1972). Non chromosomal antibiotic resistance in bacteria: genetic transformation of Escherichia coli by R-factor DNA. Proceedings of the National Academy of Sciences of the United States of America 69, 2110-2114.

DAGLEY, S. (1986). Biochemistry of aromatic hydrocarbon degradation in Pseudomonas. In The Biology of Pseudomonas: The Bacteria, vol. 10, pp. 527-555. Edited by J. R. Sokatch. New York: Academic Press.

DunN, N. W. \& Gunsalus, I. C. (1973). Transmissible plasmid coding early enzymes of naphthalene oxidation in Pseudomonas putida. Journal of Bacteriology 114, 974-979.

Ghosal, D., You, I. S. \& Gunsalus, I. C. (1987). Nucleotide sequence and expression of gene $n a h H$ of plasmid NAH7 and homology with gene $x y l E$ of TOL plasmid pWW0. Gene 55, 19-26.

HaRAYAMA, S. \& Don, R. H. (1985). Catabolic plasmids: their analysis and utilization in the manipulation of bacterial metabolic activities. In Genetic Engineering, vol. 7, pp. 283-307. Edited by J. K. Setlow \& A. Hollaender. New York: Plenum Press.

Harayama, S., Rekik, M., Wasserfallen, A. \& Bairoch, A. (1987). Evolutionary relationships between catabolic pathways for aromatics: conservation of gene order and nucleotide sequences of catechol oxidation genes of pWWO and NAH7 plasmids. Molecular and General Genetics 210, 241-247.

Hardisson, C., Sala-Trepat, J. M. \& Stanier, R. Y. (1969). Pathways for the oxidation of aromatic compounds by Azotobacter. Journal of General Microbiology 59, 1-11.

Holmes, D. S. \& Quigley, M. (1981). A rapid boiling method for preparation of bacterial plasmids. Analytical Biochemistry 114, 193197.

InouYe, S., Nakazawa, A. \& Nakazawa, T. (1981). Molecular cloning of TOL genes $x y l B$ and $x y l E$ in Escherichia coli. Journal of Bacteriology 145, 1137-1143.

Jacobsen, M. R., Premakumar, R. \& Bishop, P. E. (1986). Transcriptional regulation of nitrogen fixation by molybdenum in Azotobacter vinelandii. Journal of Bacteriology 167, 480-486.

KeIL, H. \& Williams, P. A. (1985). A new class of TOL plasmid deletion mutants in Pseudomonas putida MT15 and their reversion by tandem gene amplification, Journal of General Microbiology 131, 1023-1033.

Keil, H., Lebens, M. R. \& Williams, P. A. (1985a). TOL plasmid pWW15 contains two nonhomologous, independently regulated catechol 2,3-oxygenase genes. Journal of Bacteriology 163, 248-255.

Keil, H., KeIl, S., Pickup, R. W. \& Williams, P. A. (1985b). Evolutionary conservation of genes coding for meta pathway enzymes within TOL plasmids pWWO and pWW53. Journal of Bacteriology 164, 887-895. 
LAEMmLI, U. K. (1970). Cleavage of structural proteins during the assembly of the head of bacteriophage T4. Nature, London 227, 680 685 .

Leeman, R., Remaut, E. \& Fiers, W. (1987). A broad host range expression vector based on the $\mathrm{p}_{\mathrm{L}}$ promoter of coliphage: regulated synthesis of human interleukin 2 in Erwinia and Serratia species. Journal of Bacteriology 169, 1899-1907.

Lehrbach, P. R., MCGregor, I., Ward, J. M. \& Broda, P. (1983). Molecular relationships between Pseudomonas IncP-9 degradative plasmids TOL, NAH and SAL. Plasmid 10, 164-174.

Maniatis, T., Fritsch, E. F. \& SAMbrook, J. (1982). Molecular Cloning : a Laboratory Manual, pp. 98-148. Cold Spring Harbor, NY: Cold Spring Harbor Laboratory.

Messing, J., Crea, R. \& Seeburg, P. H. (1981). A system for shotgun DNA sequencing. Nucleic Acids Research 9, 309-321.

NaKaI, C., KagamiYana, H., Nozaki, N., NaKazawa, T., INOUYe, S., EBINA, Y. \& NaKaZAwa, A. (1983). Complete sequence of the metapyrocatechase gene on the TOL plasmid of Pseudomonas putida mt-2. Journal of Biological Chemistry 258, 2923-2928.

Neidle, E. L., Shapiro, M. K. \& OrNSTon, L. N. (1987). Cloning and expression in Escherichia coli of Acinetobacter calcoaceticus genes for benzoate degradation. Journal of Bacteriology 169, 5496-5503.

REINER, A. M. (1972). Metabolism of aromatic compounds in bacteria. Purification and properties of the catechol-forming enzyme, 3,5cyclohexadiene-1,2-diol-1-carboxylic acid $\left(\mathrm{NAD}^{+}\right)$oxidoreductase (decarboxylating). Journal of Biological Chemistry 10, 2530-2536.

Reiner, A. M. \& Hegeman, G. O. (1971). Metabolism of benzoic acid by bacteria. Accumulation of (-)-3,5-cyclohexadiene-1,2-diol-1carboxylic acid by a mutant strain of Alcaligenes eutrophus. Biochemistry 10, 2530-2536.
RoBson, R. L. (1986). Nitrogen fixation in strains of Azotobacter chroococcum bearing deletions of a cluster of genes coding for nitrogenase. Archives of Microbiology 176, 74-79.

Robson, R. L., Chesshyre, J. A., Wheeler, C., Jones, R., WoOdley, P. R. \& Postgate, J. R. (1984). Genome size and complexity in Azotobacter chroococcum. Journal of General Microbiology 130, 16031612.

Sadoff, H. L., Shimei, B. \& Ellis, S. (1979). Characterization of Azotobacter vinelandii deoxyribonucleic acid and folded chromosomes. Journal of Bacteriology 138, 871-877.

Sala-Trepat, J. M. \& Evans, W. C. (1971). The meta cleavage of catechol by Azotobacter species. European Journal of Biochemistry 20 , 400-413.

Shanley, M. S., Neidle, E. L., Parales, R. E. \& Ornston, L. N. (1986). Cloning and expression of Acinetobacter calcoaceticus catBCDE genes in Pseudomonas putida and Escherichia coli. Journal of Bacteriology 165, 557-563.

Shaw, L. E. \& Williams, P. A. (1988). Physical and functional mapping of two cointegrate plasmids derived from RP4 and TOL plasmid pDK1. Journal of General Microbiology 134, 2463-2474.

TsUDA, M. \& IINO, T. (1987). Genetic analysis of a transposon carrying toluene degrading genes on a TOL plasmid pWWO. Molecular and General Genetics 210, 270-276.

WORSEY, M. J. \& Williams, P. A. (1975). Metabolism of toluene and xylenes by Pseudomonas putida (arvilla) mt-2: evidence for a new function of the TOL plasmid. Journal of Bacteriology 124, 7-13.

Worsey, M. J., Franklin, F. C. H. \& Williams, P. A. (1978). Regulation of the degradative pathway enzymes coded for by the TOL plasmid (pWWO) from Pseudomonas putida mt-2. Journal of Bacteriology 134, 757-764. 